\title{
Okul Yöneticilerinin Motivasyonel Dili ile Öğretmen Öz Yeterliği Arasındaki İlişki Üzerine Bir Çalışma
}

\section{A Study on the Relationship Between School Administrators' Motivational Language and Teacher Self-Efficacy}

\author{
Selçuk Demir ${ }^{\text {a }}$ \\ ${ }^{a}$ Gaziantep Üniversitesi, Eğitim Bilimleri Enstitüsü, Eğitim Yönetimi, Teftişi, Planlaması ve Ekonomisi Bölümü, 27310, Gaziantep/Türkiye. \\ ORCID: 0000-0003-2904-6443
}

\section{MAKALE BİLGISİ \\ Makale Geçmişi: \\ Başvuru tarihi: 27 Ocak 2018 \\ Düzeltme tarihi: 16 Şubat 2018 \\ Kabul tarihi: 19 Şubat 2018}

\section{Anahtar Kelimeler:}

Motivasyonel Dil

Öz Yeterlik

Okul Yöneticisi

Öğretmen

\section{A R T ICLE INFO}

\section{Article history:}

Received 27 January 2018

Received in revised form 16 February 2018

Accepted 19 February 2018

\section{Keywords:}

Motivational Language

Self-Efficacy

School Manager

Teacher
ÖZ

Bu çalışmada okul yöneticilerinin kullandığı motivasyonel dil ile öğretmen öz yeterliği arasındaki ilişkinin tespit edilmesi amaçlanmıştır. Araştırmada ilişkisel tarama modeli kullanılmıştır. Araştırmanın örneklemini, Hatay il merkezinde bulunan Milli Eğitim Bakanlığına bağlı kamu ortaokullarında 2017-2018 eğitim-öğretim yılında görev yapmakta olan öğretmenler arasından yansız olarak seçilmiş 26 okulda çalışan 321 öğretmen oluşturmaktadır. Verilerin toplanmasında "Motivasyonel Dil Ölçeği”" ve "Öğretmen Öz Yeterlik Ölçeği”" kullanılmıştır. Veriler SPSS programı ile analiz edilmiştir. Araştırma bulgularına göre; okul müdürünün kullandığı motivasyonel dil öğretmen öz yeterliğini pozitif ve anlamlı olarak yordamaktadır. Ayrıca, motivasyonel dilin empatik dil alt boyutu öğretmen öz yeterliğini anlamlı olarak yordarken, yönlendirici dil ve anlam oluşturucu dil alt boyutları öğretmen öz yeterliğini anlamlı olarak yordamamaktadır. Öğretmen öz yeterliğini arttırmak için okul yöneticisinin algılanan motivasyonel dilini güçlendirme ve geliştirmeye yatırım yapmalarında fayda görülmektedir.

\section{A B S T R ACT}

In this study, it was aimed to determine the relationship between school administrators' motivational language and teacher self-efficacy. Survey-based relational design was used. The research sample consists of 321 teachers in 26 schools that were selected randomly from the middle schools affiliated to the Ministry of National Education at Hatay's city center in 2017-2018 academic year. Data analyses were performed with the program of SPSS. Data were collected by "Motivational Language Scale" and "Teacher Self-Efficacy Scale". According to the study findings, motivational language used by school administrators positively and significiantly predicts teacher self-efficacy. While empathetic sub-scale and sub-dimension of motivational language significantly predict teacher selfefficacy, directing-giving and meaning-making do not predict. It may be beneficial for school managers to invest in developing and strengthening motivational language in order to enhance teacher self-efficacy.

\section{Giriş}

Başarılı yöneticiler aynı zamanda örgütlerinin liderleridir. $\mathrm{Bu}$ yöneticiler çalışma arkadaşlarının kendilerinden daha iyi olmaları için kararlı ve cesur davranır. Çalışma arkadaşları iyi olursa kendisinin de daha iyi olacağını bilir (Templar, 2011). Bu tür yöneticiler astlarının bilgi, beceri ve kapasitelerine güvenirler, onlara en iyi kaynakları sunarlar. İnsanları daha fazlası ve daha iyisini yapabileceklerine ikna ederler. $\mathrm{Bu}$ tip örgüt liderleri izleyenlerine esin ve motivasyon verir, onlara yardımcı olmada manevi bir pusula olurlar (Murray, 2015).

Bireyin işle ilgili yeterlik düzeyinin az olduğunu düşünmesi çabasının miktarı ne kadar olursa olsun performansının istenilen düzeye ulaşmayacağına ilişkin algı geliştirmesine neden olur (Kreitner ve Kinichi, 2009). Bu alg1 ise bireyde enerjisini işine verememe, hedef belirleyememe ve kendine güven duymama gibi istenmeyen tutumlar oluşmasına neden olur (Tschannen-Moran ve Hoy, 2001). Robbins ve Judge (2012) bireylerin öz yeterlik algılarının yüksek olmasının

\footnotetext{
* Sorumlu yazar/Corresponding author.

e-posta: selcuk_demirs@hotmail.com
} 
zorlu bir görevi başarmada kendi yeteneklerine güven duymalarını arttıracağını ifade eder. Betoret ve Artiga (2010) ise öz yeterlik inancının olumlu tutumları arttıran ve olumsuz tutumlarla başa çıkılmasına etkili stratejiler sunan önemli bir örgütsel kolaylaştırıcı olduğunu belirtir.

Lider stratejik sözel iletişimleri aracılığıyla astların gizil güçlerini açı̆̆a çıkarır ve örgütün verimliliğinin arttırılması için kullanmalarını sağlar. Hefferon ve Boniwell (2011) yöneticilerin çalışanlarının verilen görevi yerine getirmesi hususunda gerekli yeteneklere sahip olduğunu hissettirmesinin önemini vurgular. Bunun ise sözel teşviklerle yapılabileceğini ifade eder. Sözel teşviklerin sunulmasının psikolojik bir süreci tetiklediği bilinmektedir. Bu bağlamda motivasyonel dilin anahtar çalışan çıktıları elde edilmesini sağlayan öz yeterlik inancı üzerindeki etkisi önem kazanmaktadır.

\section{Alanyazın Taraması}

\subsection{Motivasyonel Dil}

Motivasyonel dil teorisi çalışan çıktılarının istenilen yönde olması amacıyla başarılı yöneticilerin sözel iletişimlerine odaklanma yoluyla anlaşılır ve kolay uygulanabilir bir model önerir (Sullivan, 1988). Bu model dört varsayımdan oluşmaktadır. Birinci olarak motivasyonel dil sözel iletişimin anlamlı ve küçük birimleri olan üç dil ediminin birleşiminden oluşur. $\mathrm{Bu}$ dil edimleri yönlendirici dil, empatik dil ve anlam oluşturucu dil edimi olmak üzere üç unsurdan oluşur (Mayfield, Mayfield ve Kopf, 1995, 1998; Sullivan, 1988). Yönlendirici dil liderin belirsizliği azaltma yoluyla çalışanlara görevler, ödüller ve hedefler konusunda açıklamalar yaptığında kullanılmış olmaktadır. $\mathrm{Bu}$ dilin kullanımı örgütsel düzenlemeler ve faaliyetler hakkında çalışanların net bir şekilde bilgilendirilmesine katkı sunar. Empatik dil çalışanların başarılarından övgü ile söz edilmesi, iş ve kişisel sorunlarına özel ilgi gösterilmesi, şefkat ve değer verilmesi, anlayışlı ve kibar davranılması durumlarında oluşur (Brannon, 2011; Mayfield ve Mayfield, 2002; Mayfield, Mayfield ve Kopf, 1995, 1998; Sullivan, 1988). Anlam oluşturucu dil liderler her örgütün kendine özgü kültürünü, yapısını ve değerlerini çalışanlara aktardığında ortaya çıkar. Bu dilin kullanımında sıklıkla edebi sanatlar, metafor ve öykülerden yararlanılır (Conger, 1991).

Motivasyonel dil teorisinin sunduğu modelin ikinci varsayımı, liderlerin davranışlarının söylemleri ile tutarlılık göstermesidir. Ancak bu şekilde çalışanlar liderlerin niyetlerini açık bir şekilde anlarlar. Üçüncüsü ise, liderin uygun zamanlarda bu üç dil ediminden faydalanmasının onları en iyi sonuca götüreceğini varsaymasıdır (GutierrezWirsching vd., 2015; Mayfield vd., 1995; Sullivan, 1988). Dördüncü varsayımı ise sadece yöneticiden astlara iletişim değil, astlardan yöneticilere doğru da bir iletişimin gerçekleşmesini olanaklı kılmasıdır. Çalışanlar bu sayede yöneticileriyle açık iletişim kurabilirler. Ayrıca çalışanların kararlara katılımları da bu yolla arttırılabilir.

\section{2. Öz yeterlik}

Özyeterlik, bireylerin hedeflerine ve istedikleri sonuçlara ulaşabileceklerine olan inançlarıdır (Bandura, 2002; Kreitner ve Kinichi, 2009). Kişinin belli bir görev karşısında başarılı olacağına inanç taşıması olarak adlandırılan öz yeterlik, yapabilirimin gücü şeklinde de ifade edilebilir (Hefferon ve Boniwell, 2011). Özyeterlik inançları, bireylerin motive olmaları, mutlu olmaları ve kişisel olarak başarı elde etmeleri için psikolojik bir kaynaktır (Betoret ve Artiga, 2010). Nitekim bireyler çabalarının elde etmek istedikleri sonuca ulaştıracağına inanmadıkça harekete geçmek için oldukça az inisiyatif alırlar (Hefferon ve Boniwell, 2011).

Öz yeterlik teorisini geliştiren Bandura (1997), özyeterliğin geçmiş tecrübeler, rol modellerin başarıları, sözel teşvikler ve fizyolojik durum olmak üzere dört faktörle gelişeceğini ileri sürer. Bandura' ya göre özyeterlik algısını en çok yükselten geçmiş tecrübelerdir. Eğer geçmişte bir işi başarıyla gerçekleştirmişseniz benzer bir işi de başarabileceğinize inancınız artar. Rol modellerin başarıları ise bireyin gözlemlediği kişi ile benzer özelliklere sahip olduğunu düşündüğünde etkili olur. Gözlemlenen kişi başarılı olduğunda gözlemleyen kişinin de başarılı olacağına ilişkin güveni artar (Lunenburg ve Ornstein, 2012). Üçüncü kaynak ise sözel teşviklerdir. Bireye belirli bir görevi yerine getirmesi konusunda gerekli yeteneklere sahip olduğunun hissettirilmesidir (Hefferon ve Boniwell, 2011). Son olarak Bandura (1997) fizyolojik durumun özyeterliğe olumlu katkıda bulunacağını ileri sürmektedir.

Tschannen-Moran et al. (1998) öz yeterlik inancının eğitim örgütlerine öğretimsel stratejiler, sınıf yönetimi ve öğrenci katılımı olmak üzere başlıca üç önemli boyutta katkı yapacağını açıklamaktadırlar. Eğitimsel stratejiler öğretmenlerin öğretimsel kabiliyetleri ile ilişkili olup, sınıf yönetimi boyutu öğretmenlerin sınıfı etkili bir şekilde organize edebilme yeteneklerini sergileyebilmeleri ile ilişkilidir. Öğrenci katılımı boyutu ise derslere aktif bir şekilde öğrenci katılımının sağlanması ve öğrencilerin motive olmalarını sağlama ile ilgilidir.

\subsection{Araştırmanın Amacı}

Liderin stratejik iletişiminin örgütlerde istenen çalışan çıktıları üzerinde olumlu etkileri bulunduğu önceki çalışmalardan bilinmektedir (Brannon, 2011; GutierrezWirsching vd., 2015; Mayfield ve Mayfield, 2002; Mayfield vd., 1995, 1998; Sullivan, 1988). Lider sözel iletişimi ile ilişkili anahtar çalışan çıktılarından biri de öz yeterlik kavramidir (Guitheres-Wirsching vd., 2015). Alanda var olan eksiklikten dolayı okul yöneticilerinin motivasyonel dili ile öğretmen öz yeterliği kavramları bu araştırmada incelenmiştir. Ayrıca bu çalışmada algılanan yönetici motivasyonel dili ile öğretmen öz yeterliği arasındaki ilişkinin incelenmesinin yanı sıra öğretmenlerin öz yeterlik düzeylerinin motivasyonel dilin alt unsurları ile ilişkisi de açığa çıkarılmaya çalışılmıştır. Böylelikle motivasyonel dilin öz yeterlikle ilişkisine dair daha kapsamlı bilgiler sunulması hedeflenmiştir. $\mathrm{Bu}$ araştırma diğer örgütlerde olduğu gibi eğitim örgütlerinde de önemli performans çıktıları sunan motivasyonel dil ve öz yeterlik kavramlarına yoğunlaşılması açısından diğer çalışmalara da kuramsal çerçeve sunmaktadır. Ayrıca öğretmenlerin olumlu tutumlarını arttıran ve eğitim çevrelerine katkılar sunan öz yeterlik inançlarının geliştirilmesi ve güçlendirilmesi gerekmektedir. Bu bağlamda, okul yöneticilerinin stratejik sözel iletişimlerinde motivasyonel dilin unsurlarından yerinde ve uygun bir şekilde yararlanmaları önemli görülmektedir. Bu araştırmayla birlikte okul yöneticilerinin 
motivasyonel dil kullanımının öğretmenlerin psikolojik yapıları üzerindeki önemine ilişkin bakış açısı sunulmuştur. Araştırmanın amacı, okul yöneticilerinin öğretmenler tarafından algılanan motivasyonel dili ile öğretmen öz yeterliği arasındaki ilişkiyi belirlemektir. Bu temel amaç bağlamında aşağıdaki hipotezler geliştirilmiştir:

H1: Okul yöneticisinin motivasyonel dili öğretmen öz yeterliğini pozitif anlamlı olarak yordamaktadır.

H2: Okul yöneticisinin yönlendirici dili öğretmen öz yeterliğini pozitif anlamlı olarak yordamaktadır.

H3: Okul yöneticisinin empatik dili öğretmen öz yeterliğini pozitif anlamlı olarak yordamaktadır.

H4: Okul yöneticisinin anlam oluşturucu dili öğretmen öz yeterliğini pozitif anlamlı olarak yordamaktadır.

\section{Yöntem}

\subsection{Araştırmanın Desenlenmesi ve Uygulanması}

$\mathrm{Bu}$ araştırmada değişkenler arasındaki ilişkilerin uygulanan ölçekler aracılığıyla araştırıldığı ilişkisel tarama modeli kullanılmıştır. (Büyüköztürk vd., 2012; Karasar, 2012). İlişkisel tarama araştırması, bir grup içindeki değişkenler arasındaki ilişkiyi ve değişkenler arasında neden- sonuç olasılığına ilişkin fikir veren çalışmaları içerir (Fraenkel vd., 2012). Motivasyonel dil ve alt boyutlarının öğretmen öz yeterliği ile ilişkisi ve öz yeterliğin motivasyonel dil tarafından yordanma gücü ölçekler aracılıyla tespit edilmeye çalışılmıştır.

\subsection{Evren ve Örneklem}

Araştırmanın çalışma evreni 2017-2018 eğitim öğretim yılında Hatay il merkezindeki kamu ortaokullarında görev yapan öğretmenlerdir. $\mathrm{Bu}$ araştırmada tek tek bireylerin değil, seçkisiz olarak belirlenen grupların örneklem için seçilmesi olarak tanımlanan küme örnekleme yöntemi kullanılmıştır. Araştırmanın çalışma evreni olan Hatay il merkezinde her okul bir küme kabul edilip 26 ortaokul tesadüfî olarak seçilmiştir. Dağıtılan anketlerin 321 tanesinin geçerli olduğu görülmüş ve değerlendirmeye alınmıştır. Örneklem sayısı belirlemede, ana kütle sayısı belli olan büyüklükler için hazırlanan formüle göre alınan 321 öğretmenin \%95 güven düzeyi için yeterli olduğu görülmüştür (Özdamar, 2003; Field, 2009).

Örnekleme alınan öğretmenlerin $(\mathrm{n}=321) \% 50.2$ 'si bayan $(\mathrm{n}=161), \% 49.8$ 'i baylardan $(\mathrm{n}=160)$ oluşmaktadır. $\mathrm{Bu}$ öğretmenlerin \%74.8'i evli $(n=240)$ iken \%24.2'si bekâr öğretmenlerden $(n=160)$ oluşmaktadır. Katılımcıların en fazla bulundukları yaş aralığını \%38.3 ile 31-40 yaş aralığındaki öğretmenler $(\mathrm{n}=123)$, en az bulundukları yaş aralığını ise \%24.6 ile 41 yaş ve üstü öğretmenler $(n=79)$ oluşturmaktadır. Ayrıca katılımcıların en fazla bulundukları kıdem aralığı \%56.1 ile $1-10$ yıl arası $(n=180)$ ve en az bulundukları kıdem aralığı ise \%15 ile 21 y1l ve üzeri olduğu $(\mathrm{n}=48)$ görülmektedir.

\subsection{Veri Toplama Araçları}

Araştırma değişkenlerinin ölçümünde motivasyonel dil ve öz yeterlik ölçekleri kullanılmıştır. Ölçekler beşli likert tipinde olup seçenekler, " $1=$ Hiç katılmıyorum"; "2=
Katılmiyorum"; "3= Kismen kat1liyorum"; " $4=$ Katılıyorum"; ve "5= Tamamen katıliyorum" şeklinde değişmektedir. Katılımcılardan kendi algılarına en uygun yanıtı seçmeleri istenmiştir. Ölçeklere ilişkin bu çalışmada elde edilen bilgiler aşağıda belirtilmektedir.

Motivasyonel dil ölçeği: Bu araştırmada okul yöneticisinin motivasyonel dilinin öğretmen algısına göre ölçümü için Mayfield, Mayfield ve Kopf (1995) tarafindan geliştirilen ve Özen (2013) tarafindan Türkçe'ye uyarlanan Motivasyonel Dil Ölçeği (MDÖ) (Motivational Language Scale) kullanılmıştır. Ölçeğin orijinal formu 24 maddeden ve üç boyuttan oluşmaktadır. $\mathrm{Bu}$ araştırma kapsamında motivasyonel dil ölçeğinin Bartlett Küresellik Testi sonucu anlamlı ve Kaiser-Meyer-Olkin (KMO) katsayısı 0.956 olduğundan veri setinin faktör analizi için uygun olduğu görülmüştür. Bu çalışmadaki veri setiyle yapılan açımlayıcı faktör analizinde ölçme aracının maddeleri içerisindeki binişik (aralarındaki fark 0.10'dan küçük) olan D10 ve D18 maddeleri, boyutlarında olmayan D7, D15, D14, D13 ve D9 maddeleri ölçekten çıkarılmıştır. Başlangıçta 24 maddeden oluşan ölçme aracında faktör analizi sonrası 17 madde kalmıştır. Ölçekte maddelerin faktör yükleri 0.568 ile 0.895 arasında değiştiği tespit edilmiştir. Yönlendirici dil boyutun açıkladığı varyans yüzdesi 28.041, empatik dil (cesaret verici dil) boyutunun açıkladığı varyans yüzdesi 17.554, anlam oluşturucu dil (aitlik yaratıcı dil) boyutu tarafından açıklanan varyans yüzdesi 28.307 ve bu üç boyutun açıkladığı toplam varyans yüzdesi 73.902 olarak bulunmuştur. Cronbach's Alpha Güvenirlik Katsayısı yönlendirici dil boyutunda 0.933 , empatik dil boyutunda 0.820 , anlam oluşturucu dil boyutunda 0.935 ve ölçeğin tamamında 0.951 olduğu görülmüştür.

Öğretmen öz yeterlik ölçeği: $\mathrm{Bu}$ çalışmada Schmitz and Schwarzer (2000) tarafindan geliştirilen ve Yılmaz vd. (2004) tarafindan Türkçe'ye uyarlanan “Öğretmen Öz Yeterlik Ölçeği” kullanılmıștır. Ölçeğin 8 maddeden ve iki boyuttan oluşmaktadır. Bu araştırma kapsamında Bartlett Küresellik Testi sonucu anlamlı ve Kaiser-Meyer-Olkin (KMO) katsayısı 0.806 olduğundan veri matrisi faktör analizi için uygun olduğu görülmüștür. $\mathrm{Bu}$ araştırmada yapılan faktör analizi sonucunda ölçekten atılan madde olmamıştır. Ölçek maddelerinin faktör yükleri 0.452 ile 0.827 arasında değiştiği görülmüştür. Mücadeleci iş davranışı alt boyutunun açıkladığı varyans yüzdesi \%29.166, yenilikçi iş davranışı alt boyunun açıkladığ $\% 27.941$ ve bu iki boyutun açıkladığı toplam varyans yüzdesi \%57.107 olarak bulunmuştur. Cronbach's Alpha Güvenirlik Katsayısı başaçıkma davranışı alt boyutunda 0.725 , yenilikçi davranış alt boyutunda 0.772 ve ölçeğin tamamında 0.787 olduğu görülmüştür.

\subsection{Verilerin Analizi}

Veriler toplandıktan sonra uç değerler temizlenmiş, çarpıklık ve basıklık katsayıları kontrol edilmiş ve normallik varsayımı açısından incelenmiştir. Veriler geçerlik ve güvenirlik açısından incelenmiştir. Bu araştırma kapsamında yapılan açımlayıcı faktör analizinin sonuçları ve Cronbach's Alpha güvenirlik katsayıları kullanılan ölçeklerin geçerli ve güvenilir olduğunu göstermiştir. Bunun ardından değişkenler arasındaki ilişkiler korelasyon analizi ile tespit edilmiştir. Ardından basit ve çoklu doğrusal regresyon analizleri (stepwise yöntemiyle) kullanılarak incelenmiştir. 
Basit doğrusal regresyon analizinde bağımsız değişken motivasyonel dil; çoklu doğrusal regresyonda ise bağımsız değişkenler motivasyonel dilin yönlendirici dil, empatik dil ve anlam oluşturucu dil boyutları; her iki analizde de bağıml değişken olarak öğretmen öz yeterliği alınmıştır.

\section{Bulgular}

\subsection{Değişkenlerle İlgili Betimsel Analizler ve Korelasyon Matrisi}

Öğretmenlerin, araştırma kapsamında uygulanan ölçme araçlarındaki maddelere katılım düzeylerini gösteren aritmetik ortalama, standart sapma değerleri ile değişkenler arası ilişkilerin düzeyi ve yönünün belirtildiği korelasyon değerleri birlikte Tablo 1'de verilmektedir.

Tablo 1. Motivasyonel Dil ve Alt Boyutları İle Öz Yeterlik Ortalama, Standart Sapma Sonuçları Ve Korelasyon Değerleri

\begin{tabular}{lccccccc}
\hline Değişkenler & $\bar{X}$ & SS & 1 & 2 & 3 & 4 & 5 \\
\hline 1. Mot. Dil & 4.034 & .729 & 1 & & & & \\
2. Yön. Dil & 4.170 & .740 & $.858^{* *}$ & 1 & & & \\
3. Emp. Dil & 4.021 & .852 & $.871 * * *$ & $.659 * * *$ & 1 & & \\
4. Anl. Dil & 3.954 & .855 & $.918^{* * *}$ & $.624 * * *$ & $.759 * * *$ & 1 & \\
5. Yeterlik & 3.430 & .536 & $.186^{* *}$ & $.159 * *$ & $.187 * *$ & $.152 * *$ & 1 \\
\hline
\end{tabular}

$* \mathrm{p}<, 05, * * \mathrm{p}<, 01, * * * \mathrm{p}<, 001$

Notlar: Mot. Dil: Motivasyonel dil genel, Yön. Dil: Yönlendirici Dil, Emp. Dil: Empatik Dil, Anl. Dil: Anlam Oluşturucu Dil, Yeterlik: Öz Yeterlik

Tablo 1'e göre; okul müdürünün kullandığı motivasyonel dile, motivasyonel dilin unsurlarına ve öz yeterliğe ilişkin öğretmen algıları kısmen yüksek düzeydedir. Okulda öğretmenler tarafından en yüksek düzeyde algılanan motivasyonel dil alt boyutunun yönlendirici dil ve en düşük düzeyde algılananın ise anlam oluşturucu dil olduğu bulunmuştur. Diğer bir ifadeyle öğretmen algılarına göre yöneticiler okulda en fazla yönlendirici dili ve en az ise anlam oluşturucu dili kullanmaktadırlar. Korelasyon matrisindeki ilişkilere bakıldığında, motivasyonel dil $(\mathrm{r}=.186, \mathrm{p}<.01)$, yönlendirici dil alt boyutuna $(\mathrm{r}=.159$, $\mathrm{p}<.01)$, empatik dil alt boyutuna $(\mathrm{r}=.187, \mathrm{p}<.01)$ ve anlam oluşturucu dil alt boyutuna $(\mathrm{r}=.152, \mathrm{p}<.01)$ ilişkin algılar ile öğretmen öz yeterlik algıları arasındaki ilişkilerin pozitif anlamlı olduğu görülmektedir.

\subsection{Okul Müdürünün Kullandığı Motivasyonel Dilin Öğretmen Öz Yeterliğini Yordamas1}

Okul müdürünün kullandığı motivasyonel dilin öğretmenin öz yeterliğini yordamasına ilişkin regresyon analizi sonuçları Tablo 2'de verilmiştir. Yapılan regresyon analizinde, demografik değişkenler 1.adımda kontrol edilerek 2. adımda okul müdürünün kullandığı motivasyonel dilin, öğretmen öz yeterliğini anlamlı bir şekilde yordadığı görülmektedir $(\beta=$ $\left..185^{* *}, \quad \mathrm{p}<0.01\right)$. Öğretmenin motivasyonel dilin kullanımına ilişkin algısındaki bir birimlik artış 0.18 birimlik öğretmen öz yeterliği artışına yol açmaktadır. Okul müdürünün motivasyonel dili öğretmen öz yeterliğindeki varyansın \% 3.4' ünü açıklamaktadır $\left(\Delta \mathrm{R}^{2}=0.034\right.$; $\left.\mathrm{p}<0.01\right)$. Okul yöneticisinin motivasyonel dil kullanımına ilişkin olumlu algılar arttıkça, öğretmen öz yeterliği de artmaktadır.
Tablo 2. Okul Müdürünün Kullandığı Motivasyonel Dilin Öğretmen Öz Yeterliğini Yordamasına İlişkin Regresyon Analizi Sonuçları

\begin{tabular}{|c|c|c|c|c|c|c|}
\hline Model & Değişkenler & $\beta$ & Std. Hata & Beta & $\mathrm{t}$ & $\mathrm{p}$ \\
\hline \multirow{4}{*}{ 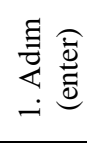 } & Sabit & 2.028 & .303 & & 6.700 & .000 \\
\hline & Cinsiyet (dummy) & .082 & .063 & 076 & 1.308 & .192 \\
\hline & Yas & .007 & .013 & .112 & .542 & .588 \\
\hline & Kidem & -.008 & .013 & -.131 & -.635 & .526 \\
\hline \multirow{5}{*}{$\begin{array}{l}\Xi \\
\frac{\Xi}{2} \\
\text { ¿ }\end{array}$} & Sabit & 1.454 & .344 & & 4.227 & .000 \\
\hline & Cinsiyet (dummy) & .075 & .062 & .070 & 1.213 & .226 \\
\hline & Yas & .008 & 013 & .125 & .613 & .540 \\
\hline & Kidem & -.008 & .013 & -.129 & -.636 & .525 \\
\hline & Motivasyonel dil & .136 & .041 & .185 & 3.349 & .001 \\
\hline
\end{tabular}

Notlar: Bağımlı değişken öz yeterlik

$\mathrm{R}^{2}$ değişim $=.034 ; \quad * \mathrm{p}<.05, * * \mathrm{p}<.01$ ve $* * * \mathrm{p}<.001$

Okul müdürünün kullandığı motivasyonel dilin alt boyutlarının öğretmen öz yeterliğini yordamasına ilişkin çoklu regresyon analizi sonuçları Tablo 3'de verilmiştir.

Tablo 3. Motivasyonel Dilin Empatik Dil Alt Boyutunun Öğretmen Öz Yeterliğini Yordamasına İlişkin Çoklu Regresyon Analizi Sonuçları

\begin{tabular}{|c|c|c|c|c|c|c|}
\hline Model & Değişkenler & $\beta$ & $\begin{array}{l}\text { Std. } \\
\text { Hata }\end{array}$ & Beta & $\mathrm{t}$ & $\mathrm{p}$ \\
\hline \multirow{4}{*}{ 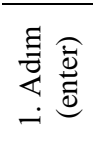 } & Sabit & 2.028 & .303 & & 6.700 & .000 \\
\hline & Cinsiyet (dummy) & .082 & .063 & .076 & 1.308 & .192 \\
\hline & Yas & .007 & .013 & .112 & .542 & .588 \\
\hline & Kidem & -.008 & .013 & -.131 & -.635 & .526 \\
\hline \multirow{5}{*}{ 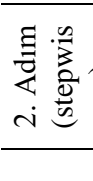 } & Sabit & 1.579 & .328 & & 4.823 & .000 \\
\hline & Cinsiyet (dummy) & .071 & .062 & .067 & 1.155 & .249 \\
\hline & Yas & .006 & .013 & .100 & .493 & .622 \\
\hline & Kidem & -.007 & .013 & -.109 & -.536 & .592 \\
\hline & Empatik dil & .115 & .035 & .183 & 3.311 & .001 \\
\hline
\end{tabular}

Bağımlı değişken öz yeterlik

$\mathrm{R}^{2}$ değişim $=0.033 ; \quad * \mathrm{p}<.05, * * \mathrm{p}<.01$ ve $* * * \mathrm{p}<.001$

Yapılan çoklu regresyon analizinde, demografik değişkenler 1.adımda kontrol edilerek 2. adımda stepwise ile motivasyonel dilin yönlendirici dil, empatik dil ve anlam oluşturucu dil boyutları modele eklendikten sonra, öz yeterlik değişkeninin motivasyonel dilin empatik dil $(\beta=$ $0.183 * *, p<0.001)$ boyutu tarafindan anlaml bir şekilde yordandığı görülmektedir. Motivasyonel dilin yönlendirici dil ve empatik dil alt boyutları öğretmen öz yeterliğini anlamlı olarak yordamadığından regresyon analizinden (stepwise yöntemiyle) elenmiștir. Her bir birimlik öğretmenin empatik dil kullanımı algısındaki artış 0.18 birimlik öğretmen öz yeterliği artışına yol açmaktadır. Okul müdürünün kullandığ 1 motivasyonel dilin empatik dil alt boyutunun öğretmen öz yeterliğindeki toplam varyansın \% 3.3'ünü açıklamaktadır $\left(\Delta \mathrm{R}^{2}=0.033 ; \mathrm{p}<0.01\right)$. Okul yöneticisinin motivasyonel dilin alt boyutu olan empatik dil kullanımına ilişkin olumlu algılar arttıkça, öğretmenin öz yeterlik düzeyinin düşük düzeyde de olsa arttığı söylenebilir.

\section{Sonuç ve Değerlendirme}

$\mathrm{Bu}$ çalışmanın sonuçlarına göre, okul yöneticilerinin algılanan motivasyonel dili öğretmen öz yeterliğini anlamlı ve pozitif yönde yordamaktadır. Ayrıca motivasyonel dilin boyutlarından sadece empatik dilin öğretmen öz yeterliğini anlamlı ve pozitif yönde yordadığı tespit edilmiştir. Dolayısıyla araştırmada test edilen hipotezlerden $\mathrm{H} 1$ ve $\mathrm{H} 3$ doğrulanmıştır. Ayrıca çalışmada, öğretmen algılarına göre okul yöneticilerinin en fazla yönlendirici dili, en az ise anlam oluşturucu dili kullandıkları bulunmuştur. 
Hefferon ve Boniwell (2011) yöneticilerin çalışanlarının görevlerini yerine getirmelerinde gerekli yeteneklere sahip olduğunu hissettirmelerinin önemli olduğunu vurgular. Bunun ise sözel teşviklerle yapılabileceğini ifade eder. Gutierrez-Wirsching ve diğerleri (2015) lider sözel iletişimi üzerine yaptıkları çalışmada ileri sürdükleri modelde lider motivasyonel dilinin çalışan bağlılığı, iş doyumu, işe devam etme, öz yeterlik, örgütsel vatandaşlık davranışı, çalışan performansı ve çalışanların yöneticiden memnuniyetini pozitif yönde etkilediğini açığa çıkarmışlardır. Önceki çalışma bulgusuna benzer olarak (Gutierrez-Wirsching vd., 2014), bu çalışmada da okul yöneticisinin algılanan motivasyonel dil kullanımının öğretmenin öz yeterlik düzeyini artırdığı tespit edilmiştir.

Empatik dil astların sorunlarıyla ilgilenilmesi, onlara ilgi ve özen gösterilmesi, anlayışlı ve kibar olunması, güven verilmesi ve onların başarılarında takdir edilmesi gibi şefkat ve değer içeren durumlarda oluştuğu önceki araştırmalarda belirtilmektedir (Mayfield vd., 1995; Sullivan, 1988). Murray (2015) ise empatik iletişimin insani duygulara temas edeceğini ve astları esinlendirici olduğunu açığa çıkarmıştır. Önceki çalışmalar (Brannon, 2011; Mayfield vd., 1995, 1998; Mayfield ve Mayfield, 2007) liderlerin empatik iletişimle, astlarıyla yakından ilgilenilebileceğini; onların bir sorunları olduğunda ya da kaygı duyduklarında onlara destek olabileceğini; zor ve stresli bir sorumluluk üstlendiklerinde onları yüreklendirebileceğini; etkili bir performans sergilediklerinde ya da başarılı olduklarında bu durumun farkına varıp onları takdir edebileceklerini ortaya koymuştur. Dolayısıyla örgüt içerisinde değer verilen, başarılarından övgü ile söz edilen, iş ve kişisel sorunlarına özel ilgi gösterilen, şefkatle gösterilen, değer verilen, kendilerini rahatça ifade etme olanağ 1 bulan ve lideri tarafindan isteklendirilen astların bilgi, beceri ve kapasitelerini kullanarak sorumluluklarından daha fazlasını yerine getirmeye ilişkin inançları güçlenir. Bu çalışmada da benzer olarak okul yöneticisinin empatik dil kullanımına ilişkin olumlu algıların artmasının öğretmenlerin öz yeterlik düzeylerini arttırdığı görülmüştür.

Önceki çalışmalarda (Chory-Assad, 2002; Lüscher ve Lewis, 2008; Mayfield ve Mayfield, 2006; Mayfield vd., 1998; Mert, 2011; Sullivan, 1988), astların algılarına göre yöneticilerin en fazla kullandığı motivasyonel dil unsurunun yönlendirici dil, en az kullandığının ise anlam oluşturucu dil olduğu görülmektedir. Dolayısıyla, öğretmen görüşlerine dayanan bu çalışmada da öğretmen algılarına göre müdürlerin en fazla kullandığı motivasyonel dil bileşeni yönlendirici dil ve en az kullanılan bileşenin ise anlam oluşturucu dil olduğu bulgusu desteklenmektedir. Bu çalışmada motivasyonel dilin empatik dil boyutunun öz yeterliği arttırdığ1 düşünüldüğünde, öğretmenlerin öz yeterlik düzeylerini arttırmak isteyen okul yöneticilerinin empatik dil kullanımına yoğunlaşmalarının önemli olduğu belirtilebilir.

Motivasyonel dil, sözel iletişimin anlamlı ve en küçük birimi olan üç söz ediminden (yönlendirici dil, empatik dil ve anlam oluşturucu dil) oluşmaktadır. Okul yöneticilerinin öğretmenlerin öz yeterlik düzeylerini arttırma ve yeniliğe açık olmaları noktasında bu üç söz ediminden uygun zamanlarda ve yerinde yararlanması önemli görülmektedir. Ayrıca okul yöneticilerinin bu bağlılığın sürekliliği için sözleri ile bu sözlerin arkasından gelen davranıșlarının uyumlu olmasının önemli olduğu düşünülmektedir.

Öz yeterlik algılarının pozitif çıktılar elde etmede örgütsel bir kolaylaştırıcı olduğu bilinmektedir (Betoret ve Artiga, 2010; Hefferon ve Boniwell, 2011). Öğretmenlerin öz yeterlik inançlarının düşünce sistemlerini, tutum ve davranışlarını etkilediği önceki çalışmalarda bulunmuştur (Busch vd., 1998; Caprara vd., 2006; Gkolia vd., 2014; Mulvaney, 2014; Rosario vd., 2009; Tschannen-Moran ve Hoy, 2001; Tschannen-Moran vd., 1998; Woolfolk ve Hoy, 1990; Yang vd., 2006). İlgili çalışmalar incelendiğinde öz yeterlik inancının iş doyumu (Caprara vd., 2006; Gkolia vd., 2014), örgütsel bağl1lık (Busch vd., 1998; Mulvaney, 2014) ve motivasyon (Rosario vd., 2009; Tschannen-Moran ve Hoy, 2001; Tschannen-Moran vd., 1998; Woolfolk ve Hoy, 1990) gibi anahtar tutumlarla pozitif yönde ilişkili olduğu görülmektedir.

Eğitim örgütlerinde öz yeterlik kavramı ile motivasyonel dil ve alt boyutlarının incelendiği bir çalışmaya rastlanılmamış olması çalışmanın özgünlüğü açısından önemlidir. $\mathrm{Bu}$ çalışma ile okullardaki yöneticilerin sözel iletişimi ile öğretmenlerin öz yeterliği arasındaki ilişkiye dair kuramsal bir çerçeve sunulmaktadır. Motivasyonel dilin en küçük ve anlamlı birimleri olan söz edimlerinin de öz yeterlikle ilişkilendirilmesi çalışmanın diğer bir önemli yanını oluşturmaktadır. $\mathrm{Bu}$ sayede kurum yöneticileri stratejik iletişimin kolay uygulanabilir bir modelini öneren Motivasyonel Dil Teorisinden daha fazla yaralanabilirler ve astları ile iletişimlerinde motive edici dil kullanımına daha fazla yoğunlaşma imkânı bulabilirler.

Sonuç olarak öz yeterlik bireylerin seçimlerini, çalışmaya duydukları isteklerini, gayret düzeylerini, stres ve kaygılarını ve engeller karşısındaki tepkilerini etkileyen psikolojik bir kavramdır. Yöneticilerin üyelerinin öz yeterlik düzeylerini geliştirici ve güçlendirici çalışmalar yapmaları gerekli görülmektedir. Araştırmada öğretmenlerin öz yeterlik düzeylerinin yöneticilerinin motivasyonel dil kullanımına bağlı olarak arttığı tespit edilmiştir. $\mathrm{Bu}$ bağlamda okul yöneticilerinin stratejik sözel iletişimin kolay uygulanabilir bir modelini öneren Motivasyonel Dil Teorisinden daha fazla yararlanmaları ve böylelikle çalışanların öz yeterlik inançlarını güçlendirecek sözel teşvikler vermeleri önerilmektedir.

\section{Kaynakça}

Bandura, A. (1997). Self-Efficacy: The Exercise of Control. New York: Freeman press.

Bandura, A. (2002). Social cognitive theory in cultural context. Journal of Applied Psychology: An International Review, 51, 269-290.

Betoret, F.G., \& Artiga, A.G. (2010). Barriers perceived by teachers at work, coping strategies, self-efficacy and burnout. The Spanish Journal of Psychology, 13(2), 637654.

Brannon, K.L. (2011). The effects of leader communication medium and motivating language on perceived leader effectiveness. Doctorate Dissertation. Arizona, USA: Northcentral University. 
Busch, T., Fallan, L., \& Pettersen, A. (1998). Disciplinary differences in job satisfaction, self-efficacy, goal commitment and organisational commitment among faculty employees in norwegian colleges: An empirical assessment of indicators of performance. Quality in Higher Education, 4(2), 137-157, http://dx.doi.org/10.1080/1353832980040204

Büyüköztürk, Ş., Çakmak, E.K., Akgün, Ö.E., Karadeniz, Ş. V., \& Demirel, F. (2012). Bilimsel Araştırma Yöntemleri. Ankara: Pegem A.

Caprara, G.V., Barbaranelli, C., Steca, P., \& Malone, P.S. (2006). Teachers' self-efficacy beliefs as determinants of job satisfaction and students' academic achievement: A study at the school level. Journal of School Psychology, 44, 473-490.

Chory-Assad R. M. (2002). Classroom justice: Perceptions of fairness as a predictor of student motivation, learning, and aggression. Communication Quarterly, 50 (1), 5877.

Conger, J. (1991). Inspiring others: The language of leadership. Academy of Management Executives, 1, 3144.

Fraenkel, J.R.,Wallen, N. E., \& Hyun, H. H. (2012). How to Design and Evaluate Research in Education. New York: McGraw-Hill.

Field, A. (2009). Discovering Statistics Using SPSS. Dubai: Oriental Press.

Gkolia, A., Belias, D., \& Koustelios, A. (2014). Teacher's job satisfaction and self-efficacy: A review. European Scientific Journal,10(22), 321-342.

Gutierrez-Wirsching, S., Mayfield, J., Mayfield, M., \& Wang, W. (2015). Motivating language as a mediator between servant leadership and employee outcomes. Management Research Review, 38(12), 1234-1250.

Hefferon, K., \& Boniwell, I. (2011). Positive Psychology: Theory, Research and Applications. New York: Mc Graw-Hill Open International Publishing Ltd..

Karasar, N. (2012). Bilimsel Araştırma Yöntemi. Ankara: Nobel Yayınlar1.

Kreitner, R., \& Kinichi, A. (2009). Organizational Behaviour. New York: Mc Graw-Hill International Edition, Ninth edition.

Lunenburg, F.C., \& Ornstein, A.C. (2012). Educational Administration: Concepts and Practices. Boston: Wadsworth Cengage Learning Publishing, Sixth Edition.

Lüscher, L. S., \& Lewis, M. W. (2008). Organizational change and managerial sensemaking: Working through paradox. Academy of Management Journal, 51 (2), 221240 .

Mayfield, J., \& Mayfield, M. (2002). Leader communication strategies: Critical paths to improving employee commitment. American Business Review, 20(2), 89-94.

Mayfield, J., \& Mayfield, M. (2006). The benefits of leader communication on part-time worker outcomes: A comparison between part-time and full-time employees using motivating language. Journal of Business Strategies,23(2), 131-153.

Mayfield, J., \& Mayfield, M. (2007). The effects of leader communication on a worker's intent to stay: An investigation using structural equation modeling. Human Performance, 20(2), 85-102, http://dx.doi.org/10.1080/08959280701332018.

Mayfield, J., Mayfield, M. \& Kopf, J. (1995). Motivational language: Exploring theory with scale development. The Journal of Business Communication, 32(4), 329-344.

Mayfield, J., Mayfield, M., \& Kopf, J. (1998). The effects of leader motivating language on subordinate performance and satisfaction. Human Resource Management, 37(3-4), 235-248.

Mert, İ. S. (2011). Yöneticilerin kullandıkları motivasyonel dil ve performans üzerindeki etkisi. Balıkesir Üniversitesi Sosyal Bilimler Enstitüsü Dergisi, 14 (26), 197-214.

Mulvaney, M.A. (2014). Leave programs/time off and workstress family employee benefits programs, organizational commitment, and self-efficacy among municipal employees. Public Personnel Management, 43(4), 459489.

Murray, K. (2015). Liderk Dili. (çev. Ümit Şensoy). İstanbul: Türkiye İş Bankası Kültür yayınları.

Murray, K. (2016). Liderlik ve İletişim. (çev. Ümit Şensoy). İstanbul: Türkiye İş Bankası Kültür yayınları.

Özdamar, K. (2003). Modern Bilimsel Araştırma Yöntemleri. Eskişehir: Kaan Kitabevi.

Özen, H. (2013). Okul müdürlerine yönelik motivasyonel dil ölçeği: Türk kültürüne uyarlama, dil geçerliği ve faktör yapısının incelenmesi. Eğitim Bilimleri Araştırmaları Dergisi, 3 (1), 87-103.

Robbins, S.P., \& Judge, T.A. (2012). Örgütsel Davranış (Çev. Ed. İnci Erdem). Istanbul: Nobel yayıncılık.

Rosario, P., Blas, R., \& Valle, A. (2009). Teachers' selfefficacy, motivation and teaching strategies. Escritos de Psicología, 3(1), 1-7.

Schmitz, G.S., \& Schwarzer, R. (2000). Selbstwirksamkeitserwartung von Lehrern: Langsschnitt befunde mit einem neuen Instrument. Zeitschrift für Pädagogische Psychologie, 14 (1), 12-25.

Sullivan, J.J. (1988). Three roles of language in motivating theory. The Academy of Management Review, 13(1),104115 .

Templar, R. (2011). The Rules of Management (Expanded edition). New Jersey: Pearson Education Limited.

Tschannen-Moran, M., Hoy, A. W., \& Hoy, W. K. (1998). Teacher efficacy: Its meaning and measure. Review of educational research, 68(2), 202-248.

Tschannen-Moran, M., \& Hoy, A. W. (2001). Teacher efficacy: Capturing an elusive construct. Teaching and Teacher Education, 17(7), 783-805. 
Woolfolk, A. E., \& Hoy, W. K. (1990). Prospective teachers' sense of efficacy and beliefs about control. Journal of educational Psychology, 82(1), 81-91.

Yang, H.L., Kao, Y.H., \& Huang, Y.C. (2006). The job selfefficacy and job involvement of clinical nursing teachers. Journal of Nursing Research, 14(3), 237-249.

Yukl, G., O'Donnell, M., \& Taber, T. (2009). Influence of leader behaviors on the leader-member exchange relationship. Journal of Managerial Psychology, 24(4), 289-299.

Yılmaz, M., Köseoğlu, P., Gerçek, C., \& Soran, H. (2004). Yabancı dilde hazırlanan bir öğretmen öz-yeterlik ölçeğinin Türkçe' ye uyarlanması. Hacettepe Üniversitesi Eğitim Fakültesi Dergisi, 27, 260-267. 